\title{
www.czasopisma.pan.pl \\ Iron Intermetallic Phases in the Alloy Based on Al-Si-Mg by Applying Manganese
}

\author{
R. Podprocká *, D. Bolibruchová \\ Department of Technological Engineering, Faculty of Mechanical Engineering, University of Žilina, Slovakia \\ *Corresponding author. E-mail address: radka.podprocka@fstroj.uniza.sk
}

Received 28.03.2017; accepted in revised form 29.06.2017

\begin{abstract}
Manganese is an effective element used for the modification of needle intermetallic phases in Al-Si alloy. These particles seriously degrade mechanical characteristics of the alloy and promote the formation of porosity. By adding manganese the particles are being excluded in more compact shape of "Chinese script" or skeletal form, which are less initiative to cracks as $\mathrm{Al}_{5} \mathrm{FeSi}$ phase. In the present article, AlSi7Mg0.3 aluminium foundry alloy with several manganese content were studied. The alloy was controlled pollution for achieve higher iron content (about 0.7 wt. \% Fe). The manganese were added in amount of 0.2 wt. \%, 0.6 wt. $\%, 1.0$ wt. \% and 1.4 wt. \%. The influence of the alloying element on the process of crystallization of intermetallic phases were compared to microstructural observations. The results indicate that increasing manganese content $(>0.2 \mathrm{wt}$. \% Mn) lead to increase the temperature of solidification iron rich phase $\left(\mathrm{TAl}_{5} \mathrm{FeSi}\right)$ and reduction this particles. The temperature of nucleation $\mathrm{Al}-\mathrm{Si}$ eutectic increase with higher manganese content also. At adding 1.4 wt. \% Mn grain refinement and skeleton particles were observed.
\end{abstract}

Keywords: $\mathrm{AlSi} 7 \mathrm{Mg} 0.3$, Needle $\mathrm{Al}_{5} \mathrm{FeSi}$ phase, Manganese

\section{Introduction}

The Al-Si alloys are mainly used in the automotive industry because of their excellent mechanical properties that are due to their good castability, low tendency to form shrinkage and cracks. The commercial AlSi7Mg0.3 alloy is widely used for casting engine blocks, cylinder heads and transmissions case etc.

Due to economic and ecological requirements are currently growing demand for secondary alloys. The production of secondary alloys except the cost savings is more energy efficient compared to primary production from ore alloys also. The iron is a common impurity mainly secondary Al-Si alloys and is harmful in one or more ways. Iron is good solubility in liquid aluminium and its alloys, in solid form the solubility decreases and leading to combining with the other elements of $\mathrm{Fe}$, and the formation of intermetallic phases. The chemical composition of the alloy and the solidification parameters are an important factor affecting the process of intermetallic compounds, which are responsible for the resulting mechanical properties.

In the presence of silicon in the alloy is formed $\mathrm{Al}_{8} \mathrm{Fe}_{2} \mathrm{Si}$ phases, respectively. $\mathrm{Al}_{12} \mathrm{Fe}_{3} \mathrm{Si}_{2}$ (both known as $\alpha$-phase) and phase $\mathrm{Al}_{5} \mathrm{FeSi}$ (known as $ß$-phase). When the alloy is present except $\mathrm{Si}$ also $\mathrm{Mg}$ is formed $\mathrm{Al}_{8} \mathrm{FeMg}_{3} \mathrm{Si}_{6}$ phase (known as a $-\pi$ ). With the increase of iron content increases the precipitation of these intermetallic phases in the form of long needles, respectively plates, which decreases the mechanical properties. These intermetallic phases reduce the tensile strength and elongation of alloys because are formed during solidification of the eutectic and can affect the castability porosity of the support the porosity $[2,3]$. Because of iron can not be easily removed from the molten alloy, the formation of the $\mathrm{Al}_{5} \mathrm{FeSi}$ phase and its negative effect can be slowed or completely removed using different neutralizerscorrectors of the iron, such as $\mathrm{Mn}, \mathrm{Cr}, \mathrm{Be}$, and $\mathrm{Ni}$. The most used is $\mathrm{Mn}$, which can achieve changes the morphology of platelet $\beta$ $\mathrm{Al}_{5} \mathrm{FeSi}$ phase to more compact, less harmful form, e.g. to the 
form of Chinese script, skeletal formations or polyhedral crystals. It is well known that the $\mathrm{Mn}$ and Fe content can influence the type, the size and the ratio of different $\mathrm{Fe}$ intermetallic compounds. Furthermore, a $\mathrm{Mn} / \mathrm{Fe}$ ratio of 0.5 is recommended even though the amount of Mn needed to neutralize Fe has not been well established $[4,5]$.

\section{Experiments methodology}

The chemical composition of the examined alloy AlSi7Mg0.3 is shown in Tab. 1. The alloy was controlled pollution in the form of master alloys AlFe10. The critical iron level present in the alloy is directly related with $\mathrm{Si}$ amount and it can be calculated according to relation (1) [1].

$$
F e_{k r i t} \approx 0,075 x(\% S i)-0,05
$$

Amount of iron was established according (1) and above the value allowed the standard ( $0.6 \mathrm{wt}$. \%). The obtain secondary alloy with content 0.7 wt. $\% \mathrm{Fe}$ was used to prepare of alloys with different manganese content. The chemical composition of the alloy with about 0.7 wt. $\% \mathrm{Fe}$ is shown in the table 2 .

Table1.

Chemical composition (wt.\%) of alloy AlSi7Mg0.3

\begin{tabular}{ccccc}
\hline $\mathrm{Si}$ & $\mathrm{Fe}$ & $\mathrm{Cu}$ & $\mathrm{Mn}$ & $\mathrm{Mg}$ \\
\hline 7,093 & 0,099 & $<0,0020$ & 0,072 & 0,38 \\
\hline $\mathrm{Zn}$ & $\mathrm{Ti}$ & $\mathrm{Sr}$ & $\mathrm{Al}$ & $\mathrm{Mn} / \mathrm{Fe}$ \\
\hline 0,0054 & 0,18 & 0,015 & 92,14 & 0,48 \\
\hline
\end{tabular}

Table 2.

Chemical composition (wt.\%) of secondary alloy AlSi7Mg0.3

\begin{tabular}{ccccc}
\hline $\mathrm{Si}$ & $\mathrm{Fe}$ & $\mathrm{Cu}$ & $\mathrm{Mn}$ & $\mathrm{Mg}$ \\
\hline 7,31 & 0,778 & $<0,0050$ & 0,071 & 0,299 \\
\hline $\mathrm{Zn}$ & $\mathrm{Ti}$ & $\mathrm{Sr}$ & $\mathrm{Al}$ & $\mathrm{Mn} / \mathrm{Fe}$ \\
\hline 0,0047 & 0,135 & 0,011 & 91,37 & 0,09 \\
\hline
\end{tabular}

The recommended addition to eliminate the harmful effects of iron is $\mathrm{Mn}: \mathrm{Fe}=1: 2$ or if an iron amount exceeds a value of the mass fraction $\mathrm{w}=0.45 \%$, the recommended addition of $\mathrm{Mn}$ should not be lower than half of the iron amount [1]. The additions of manganese were established according [1] in an amount of 0.2 wt. \%, 0.6 wt. \%, 1.0 wt. \%, 1.4 wt. \%. The required amount of manganese was achieved by adding master alloys AlMn20. The chemical composition of the alloy with the addition of manganese is shown in Tab. 3 . The alloys were melted in an electric resistance furnace in a graphite crucible with protective coating. The samples were poured into a metal mould preheated to a temperature of $200 \pm 5^{\circ} \mathrm{C}$ at $760 \pm 5^{\circ} \mathrm{C}$. The melt was not further modified, grain refined or purified.
Table 3.

Chemical composition (wt.\%) of secondary alloy AlSi7Mg0.3 after adding of manganese

\begin{tabular}{|c|c|c|c|c|}
\hline $\mathrm{Si}$ & Fe & $C_{1}$ & $M n$ & $M$ \\
\hline 7,355 & 0823 & $<00020$ & 0309 & 0396 \\
\hline $\mathrm{Zn}$ & $\mathrm{Ti}$ & $\mathrm{Sr}$ & $\mathrm{Al}$ & $\mathrm{Mn} / \mathrm{Fe}$ \\
\hline 0,0062 & 0,137 & 0,0086 & 90,93 & 0,38 \\
\hline II. & 0.6 wt. $\% \mathrm{Mn}$ & & & \\
\hline $\mathrm{Si}$ & $\mathrm{Fe}$ & $\mathrm{Cu}$ & $\mathrm{Mn}$ & $\mathrm{Mg}$ \\
\hline 6,916 & 0,753 & $<0,0020$ & 0,699 & 0,36 \\
\hline $\mathrm{Zn}$ & $\mathrm{Ti}$ & $\mathrm{Sr}$ & $\mathrm{Al}$ & $\mathrm{Mn} / \mathrm{Fe}$ \\
\hline 0,0059 & 0,134 & 0,0043 & 91,1 & 0,93 \\
\hline III. & 1.0 wt. $\% \mathrm{Mn}$ & & & \\
\hline $\mathrm{Si}$ & $\mathrm{Fe}$ & $\mathrm{Cu}$ & $\mathrm{Mn}$ & $\mathrm{Mg}$ \\
\hline 6,67 & 0,585 & 0,0027 & 0,874 & 0,347 \\
\hline $\mathrm{Zn}$ & $\mathrm{Ti}$ & $\mathrm{Sr}$ & $\mathrm{Al}$ & $\mathrm{Mn} / \mathrm{Fe}$ \\
\hline 0,0035 & 0,139 & 0,011 & 91,34 & 1,49 \\
\hline IV. 1 & 1.4 wt. $\% \mathrm{Mn}$ & & & \\
\hline $\mathrm{Si}$ & $\mathrm{Fe}$ & $\mathrm{Cu}$ & $\mathrm{Mn}$ & $\mathrm{Mg}$ \\
\hline 6,450 & 0,629 & 0,0036 & 1,232 & 0,354 \\
\hline $\mathrm{Zn}$ & $\mathrm{Ti}$ & $\mathrm{Sr}$ & $\mathrm{Al}$ & $\mathrm{Mn} / \mathrm{Fe}$ \\
\hline 0,0049 & 0,135 & 0,0087 & 91,16 & 1,96 \\
\hline
\end{tabular}

The process of crystallization iron-based intermetallic phases in secondary alloy with different of manganese content was evaluated by using thermal analysis. During the measurement was used a thermocouple of type $\mathrm{K}(\mathrm{NiCr}-\mathrm{Ni})$ situated in the centre of a cylindrical metal mould with a diameter of $34 \mathrm{~mm}$ and height of $50 \mathrm{~mm}$. The values were recorded in the program LabView of 2 $\mathrm{Hz}$. From the measured values were made cooling curves and their first derivatives to accurately determine the characteristic temperature for crystallization of the alloy. From obtained of cooling curves was determined: the temperature of liquid (Tliq), the temperature of solidification primary dendrites of $\alpha$-phase $(\mathrm{T} \alpha)$, the temperature of solidification of iron rich phase $\left(\mathrm{TAl}_{5} \mathrm{FeSi}\right.$ ), the temperature of nucleation $\mathrm{Al}-\mathrm{Si}$ eutectic TAl-Si), the temperature of nucleation magnesium rich phases $\left(\mathrm{TMg}_{2} \mathrm{Si}\right)$ and temperature of solidus (Tsol). The sample of cooling curve and its first derivate is shown in Fig. 1.

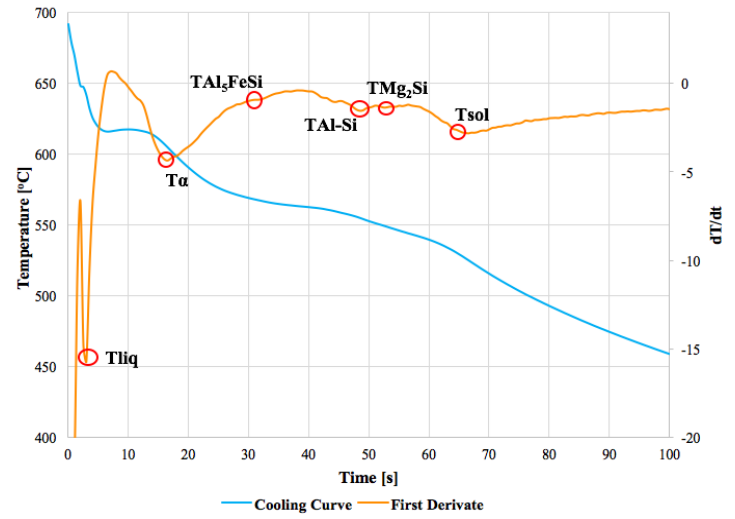

Fig. 1. Cooling curve and its first derivate of secondary alloy AlSi $7 \mathrm{Mg} 0.3$ with 0.2 wt. $\% \mathrm{Mn}$ 


\section{Results}

During the cooling of alloy melt from the evolution of heat, the temperature decreases and it leads to exclusion of intermetallic phases. By the specific temperature occur a phase transitions, which are accompanied by release of heat. The characteristics of temperatures of secondary alloy AlSi7Mg0.3 with different addition of manganese are shown in Fig. 2 and Tab. 4. The temperature of liquid is between $622.72{ }^{\circ} \mathrm{C}(1.4$ wt. \% Mn) and $648.32{ }^{\circ} \mathrm{C}(1.0$ wt. \% Mn). The temperature of formation of primary dendrites of $\alpha$-phase has increasing character after the addition of 0.2 wt. $\% \mathrm{Mn}$, after the addition of 1.4 wt. $\% \mathrm{Mn}$ decreasing slightly.

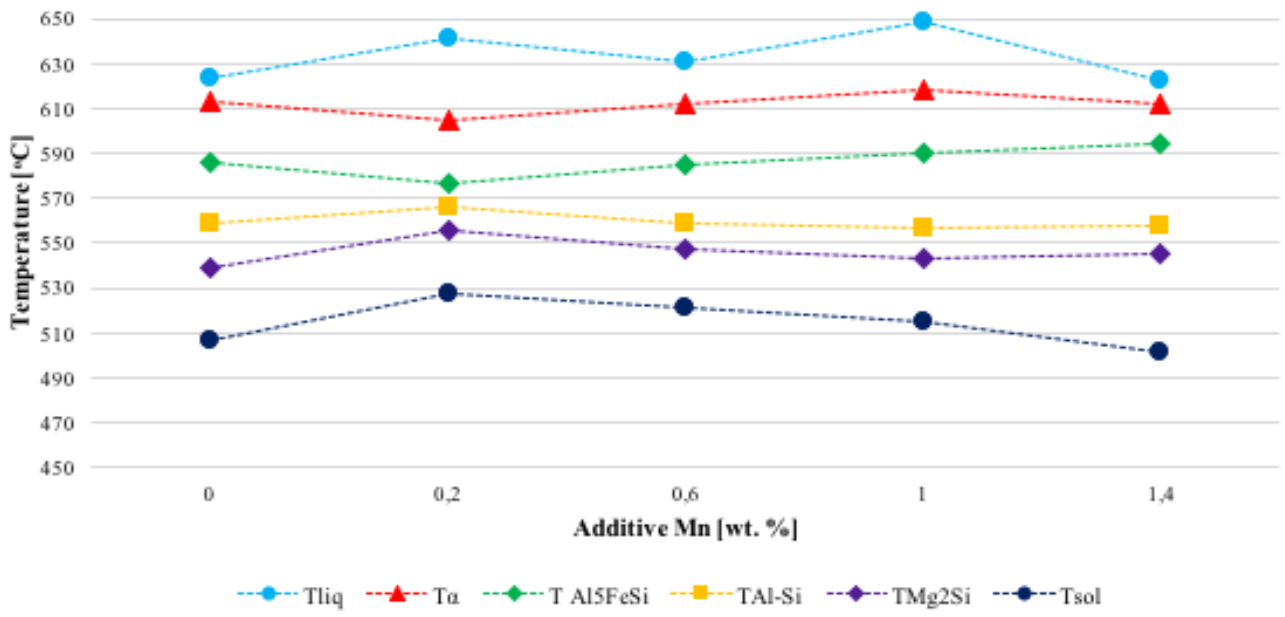

Fig. 2. Temperature of characteristic reaction of secondary alloy AlSi7Mg0.3 with different additives of manganese

Table 4.

Temperature of characteristic reaction of secondary alloy AlSi7Mg0.3 with different additives of manganese

\begin{tabular}{ccccccc}
\hline Alloy & Tliq $\left({ }^{\circ} \mathrm{C}\right)$ & $\mathrm{T} \alpha\left({ }^{\circ} \mathrm{C}\right)$ & $\mathrm{TAl}_{5} \mathrm{FeSi}\left({ }^{\circ} \mathrm{C}\right)$ & $\mathrm{TAl}-\mathrm{Si}\left({ }^{\circ} \mathrm{C}\right)$ & $\mathrm{TMg} 2 \mathrm{Si}\left({ }^{\circ} \mathrm{C}\right)$ & $\mathrm{Tsol}\left({ }^{\circ} \mathrm{C}\right)$ \\
\hline AlSi7Mg0,3 & 623.14 & 612.84 & 585.78 & 558.77 & 538.67 & 506.14 \\
\hline AlSi7Mg0.3 + 0.2 wt. \% Mn & 641.46 & 604.59 & 576.90 & 566.43 & 555.43 & 527.68 \\
\hline AlSi7Mg0.3 + 0.6 wt. \% Mn & 631.11 & 612.40 & 585.26 & 559.13 & 547.23 & 521.16 \\
\hline AlSi7Mg0.3 + 1.0 wt. \% Mn & 648.32 & 618.60 & 589.68 & 557.15 & 543.46 & 515.00 \\
\hline AlSi7Mg0.3 + 1.4 wt. \% Mn & 622.72 & 611.96 & 594.22 & 557.78 & 544.75 & 501.33 \\
\hline
\end{tabular}

Manganese addition in amount of 0.2 wt. \% lead to the decrease of temperature of solidification intermetallic $\mathrm{Al}_{5} \mathrm{FeSi}$ phase. The formation of this phase presents the reaction: $\mathrm{L} \rightarrow \alpha$-phase $+\mathrm{Si}+$ $\mathrm{Al}_{5} \mathrm{FeSi}$ [4]. At this addition has been needle of $\mathrm{Al}_{5} \mathrm{FeSi}$ observed evenly distributed in a matrix of aluminium and along silicon eutectic (Fig. 3). The other additions of manganese caused the increase of temperature formation $\mathrm{Al}_{5} \mathrm{FeSi}$ phase, which is probably related to the change in the structure at higher additions.

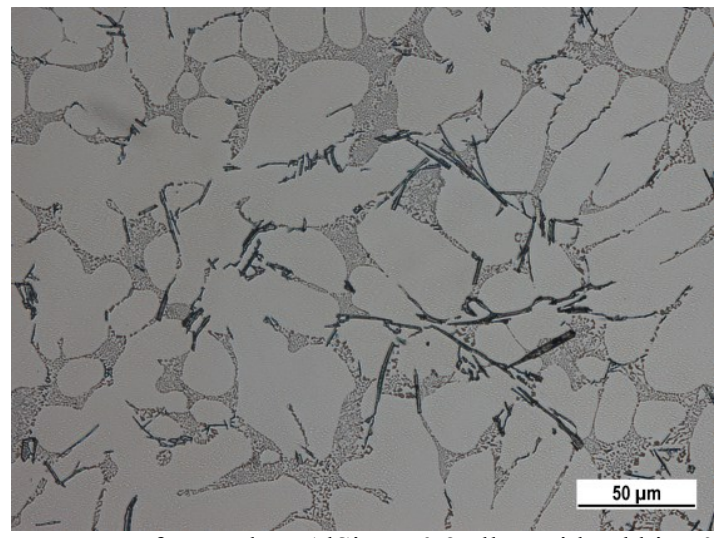

Fig. 3. Microstructure of secondary AlSi7Mg0.3 alloy with addtive 0.2 wt. $\% \mathrm{Mn}$ 
Manganese addition in amount of $0.6 \mathrm{wt}$. \% lead to change of morphology needle $\mathrm{Al}_{5} \mathrm{FeSi}$ phase into skeleton particles, but mostly were present needle of $\mathrm{Al}_{5} \mathrm{FeSi}$ phase. As it can be seen in Fig. 5, manganese caused reduction of particles of $\mathrm{Al}_{5} \mathrm{FeSi}$ phase

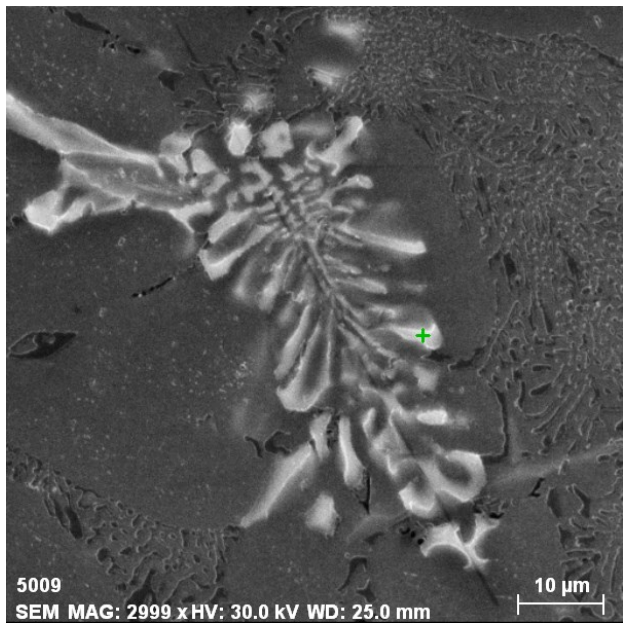

Fig. 4. EDX analysis of skeletal phase of secondary AlSi7Mg0.3 with additive 0.6 wt. \% compared to the addition of Mn 0.2 wt. \%. EDX analysis of the skeleton particles is shown in Fig. 4. The ratio of $\mathrm{Mn} / \mathrm{Fe}$ is 0.93 as confirmed by the result of the chemical composition of the skeletal phase.

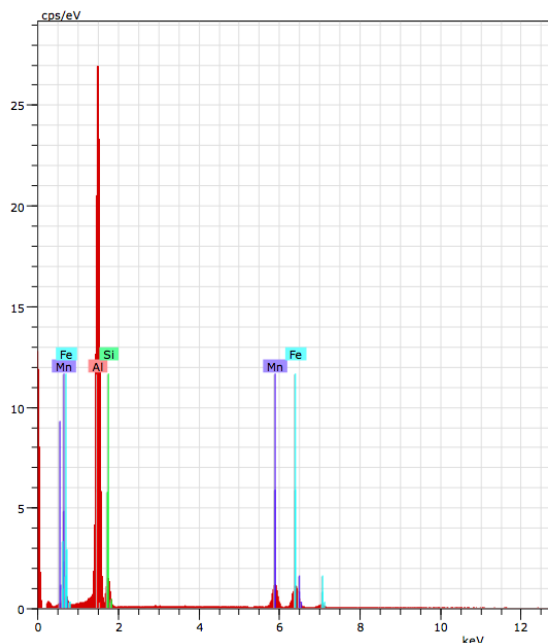

Microstructure contains more skeletal formations after addition of 1.0 wt. $\% \mathrm{Mn}$ and there was a "fragmentation" intermetallic $\mathrm{Al}_{5} \mathrm{FeSi}$ phases also (Fig. 5a). Transformative manganese by [1] associated with the reaction $\mathrm{L}+\mathrm{Al}_{5} \mathrm{FeSi} \rightarrow \mathrm{Al}+\mathrm{Si}+$ $\mathrm{Al}_{15}(\mathrm{FeMn})_{3} \mathrm{Si}_{2}$ when the plates of $\mathrm{Al}_{5} \mathrm{FeSi}(\beta$-phase) transformed to the $\mathrm{Al}_{15}(\mathrm{FeMn})_{3} \mathrm{Si}_{2}$ phase of skeletal morphology or shape "Chinese script" or polyhedral crystals. When the manganese increased 1.4 wt. \% is rarely needle $\mathrm{Al}_{5} \mathrm{FeSi}$ phase observed. Microstructure of alloy were present small skeleton crystal or long skeleton particles. These phases in the alloy structure was located along the grain boundaries and has been their refinement also. Distribution of these phases reminds the larger partial "network". EDX analysis of such phase is shown in Fig. 6. The manganese content is lower than after addition $0.6 \mathrm{wt} \% \mathrm{Mn}$. The presence of significant amount of manganese and iron caused the formation of "sludge" phase also (Fig. 5b).

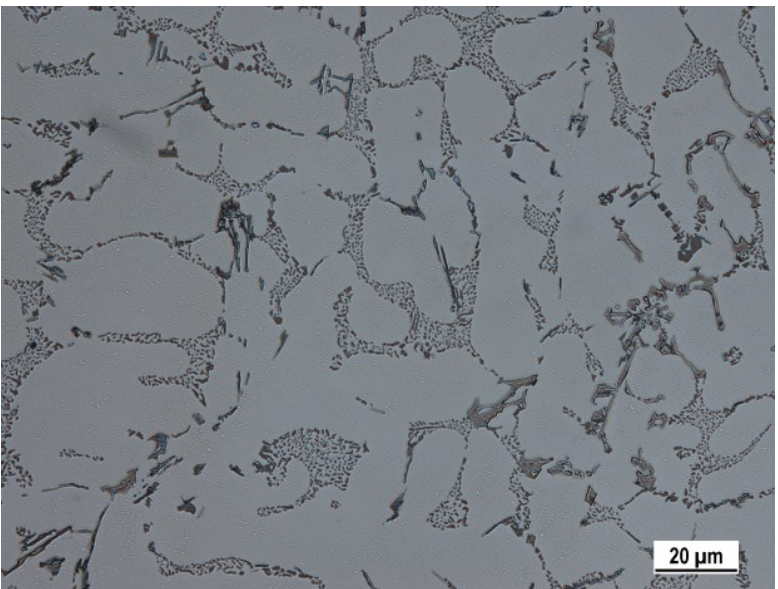

a)

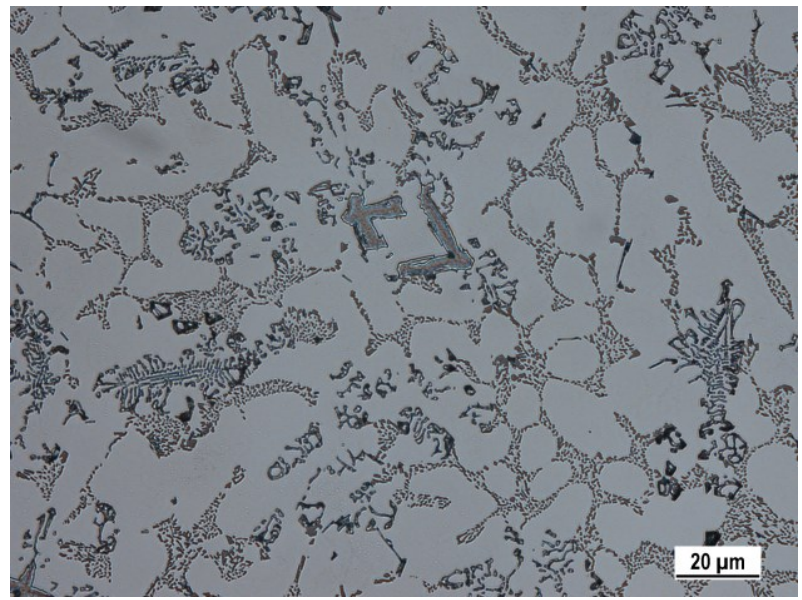

b)

Fig. 5. Microstructure of secondary AlSi7Mg0.3 alloy with addtive:

a) 1.0 wt. $\% \mathrm{Mn}$, b) 1.4 wt. $\% \mathrm{Mn}$ 

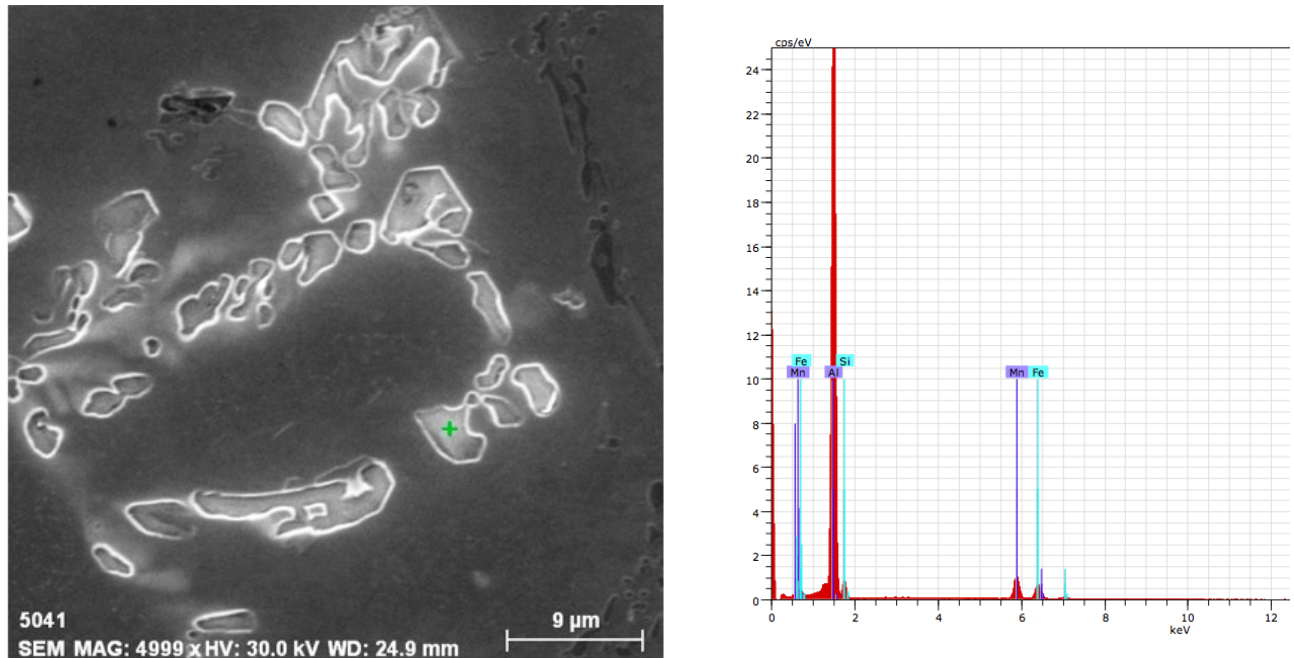

Fig. 6. EDX analysis of small skeletal phase of secondary AlSi7Mg0.3 with additive 1.4 wt. \%

The temperature corresponding to the formation of eutectic silicon (Tab. 4, Fig. 2) was increased by the addition of 0.2 wt. \% Mn by $18.3{ }^{\circ} \mathrm{C}$. The temperature of nucleation Al-Si eutectic decrease by the other additions. Decrease of temperature in eutectic reaction and higher concentrations of manganese with the presence of iron seems to cause softening of silicon observed by $1.4 \mathrm{wt}$ \% $\mathrm{Mn}$. The lowest temperature of solidus (Tab. 4, Fig. 2) was observed after addition of $1.4 \mathrm{wt} . \% \mathrm{Mn}$, which is probably related to the formation of sludge phases. These phases occur at low temperatures or rapid cooling of metal. This is due to its high melting point, high specific gravity and hardness which causes the increasing wear of melting devices and deteriorating of the alloy machinability. Except of this, once the sludge phase is formed, it cannot be removed from alloy by further re-melting or re-melting process $[1,5]$.

\section{Conclusions}

According to the experimental findings the following conclusions that higher manganese content $(>0.2 \mathrm{wt}$ \% $\%$ ) caused the increasing the temperature of formation $\mathrm{Al}_{5} \mathrm{FeSi}$ phase and their reducing also. The structural change of the alloy were observed after addition of 0.6 wt. \% Mn. Higher amount of manganese caused to replace needle $\mathrm{Al}_{5} \mathrm{FeSi}$ phase to skeleton particles of $\mathrm{Al}_{15}(\mathrm{FeMn})_{3} \mathrm{Si}_{2}$ phase. The temperature of nucleation $\mathrm{Al}-\mathrm{Si}$ eutectic is increased after the addition of $0.2 \mathrm{wt} \% \mathrm{Mn}$ and manganese addition in amount of $1.4 \mathrm{wt}$ \% caused also grain refinement and skeleton particles. Microstructure contains at higher content of Mn (1.0 wt.\%, 1.4 wt.\%) of small skeleton particles or long skeleton which are mainly excluded in the grain boundaries. Mutual combination of higher amount of iron along with manganese $(<1.4 \mathrm{hm} . \% \mathrm{Mn})$ at the same time also caused the formation "sludge phases".

\section{References}

[1] Taylor, J.A. (2012). Iron-containing intermetallic phase in Al-Si based casting alloys. Procedia Materials Science. 1, 19-33.

[2] Shabestari S.G., 2004. The effect of iron and manganese on the formation of intermetallic compounds in aluminiumsilicon alloys. Materials Science and Engineering A. 383, 289-298.

[3] Dinnis, C.M. et al. (2005). As-cast morphology of ironintermetallics in Al-Si foundry alloys. Scripta Materialia. 53(8), 955-958.

[4] Tillová, E., Chalupová, M. (2009). Structural analysis of AlSi cast alloys. Žilina: EDIS.

[5] Bolibruchová, D., Macko, J., Brůna, M.(2014) Elimination of negative effect of $\mathrm{Fe}$ in secondary alloys AlSi6Cu4 (EN AC 45 000, A 319) by nickel. Archives of Metallurgy and Materials. 59(2), 717-721.

[6] Pastirčák, R., Ščury, J. (2016). Effect of technological parameters on microstructure in alloy $\mathrm{AlCu} 4 \mathrm{Ti}$ using squeeze casting. American Institute of Physics Publising. 1745. 